http://kitaibelia.unideb.hu/

ISSN 2064-4507 (Online) • ISSN 1219-9672 (Print)

(C) Department of Botany, University of Debrecen, Hungary

27(1): 86-101.; 2022

DOI: $10.17542 /$ kit.27.001

research paper • eredeti közlemény

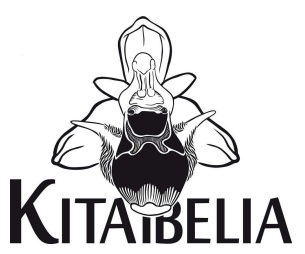

\title{
Adatok a vasútmenti pionír élőhelyek flórájához a Tiszántúlon
}

\author{
KIs Szabolcs \\ Debreceni Egyetem, H-4032. Debrecen, Egyetem tér 1.; kis.szabi17@gmail.com
}

\section{Contributions to the flora of railway-side pioneer habitats on Tiszántúl region}

\begin{abstract}
Verges have considerable importance to preserve diversity in arable landscape. The modernized railway embankments are a great surface to the spread of native pioneer or adventive (invasive) plant species. The new data are about the flora of railway embankments mainly from Tiszántúl region. I present some species found on railway verges (e.g. Equisetum ×moorei, Equisetum ramosissimum, Lycopsis arvensis, Euphorbia maculata, Lepidium densiflorum Tragus racemosus, Vulpia myuros). An especially important new data is the refinding of Galium humifusum in Hungary. Locally non-native and adventive species can use the blanketing materials (sand or gravel) of railway embankments as dispersal corridor and colonize them. The railwayside habitats could contribute to the conservation of rare native pioneer species.
\end{abstract}

Keywords: alien species, Equiestum $\times$ moorei, Galium humifusum, pioneer flora, railwayside pioneer habitats, railway verges

Összefoglaló - A vasúti pályaszakaszok (vonalas létesítmények) mentén létrejövő pionír élőhelyek kiváló terjedési lehetőséget biztosítanak egyes fajok számára. A dolgozatban olyan, a vasúti töltéseken fellelt fajok új előfordulásait mutatom be, mint az Equisetum ×moorei, Equisetum ramosissimum, Lycopsis arvensis, Euphorbia maculata, Lepidium densiflorum, Tragus racemosus és a Vulpia myuros. Kiemelendő adat a Galium humifusum újrafelfedezése az országban. A dolgozatban összegyűjtött adatok alapján elmondható, hogy egyes adventív, illetve nem tájhonos (homokgyepi) fajok ezen vasúti töltések homokalapzatait képesek kolonizálni, így azokat ökológiai folyosóként használni. Ezáltal a vasútmenti pionír élőhelyek jelentős szerepet játszanak az adventív fajok terjeszkedésében, ugyanakkor az országosan ritka, őshonos pionír fajok megtelepedésére is lehetőséget adnak.

Kulcsszavak: adventív fajok, Equisetum ×moorei, Galium humifusum, pionír növényzet, vasútmenti pionír élőhelyek, vasúti mezsgyék

\section{Bevezetés és célkitűzés}

A vasutak mentén elhelyezkedő élőhelyek között meg kell különböztetnünk a mezsgyéket és a vasúti pálya kiépítésével és fenntartásával létrejövő pionír élőhelyeket. A mezsgyék közé tartoznak mindazon keskeny, hosszanti, megműveletlen földsávok, melyeket utak és vasutak mentén, szántóföldek, illetve egyéb művelt területek (pl. szőlők és gyümölcsösök) közötti határon hagytak meg. Ezekben olykor az adott terület eredeti növényzete vagy annak bizo- 
nyos elemei fennmaradhatnak. A hazai mezsgyék fontosságára és ökológiai, természetvédelmi szerepére már többen is felhívták a figyelmet (JАKAB 2005, SUTYINSZKI et al. 2013). Kiemelkedő a Csanádi-löszhát példája, ahol az intenzív mezőgazdasági művelés miatt mára csupán a mezsgyékben maradtak fenn az eredeti löszvegetáció fragmentumai (CSATHó 2009, CSATHó \& CSATHó 2010).

Ettől elkülöníthető rendszert alkotnak a vasútmenti pionír élőhelyek, ahol a felszín jelentős átalakításon ment keresztül. A létrejövő pionír felszínt általában a gyorsan és tömegesen megjelenő, gyakran adventív fajok (Ambrosia artemisiifolia, Erigeron annuus, Conyza canadensis, Senecio vernalis) árasztják el (Denisow et al. 2017). Az adventív fajok vasútmenti pionír élőhelyeken történő kolonizációjára példa a kifejezetten vasútvonalak mentén terjedő Oxybaphus nyctagineus, mely a budapesti agglomeráció vasútállomásain, északmagyarországi, illetve Duna-Tisza közi vasútállomásokon került elő (BÁTORI et al. 2014, MolnÁR \& JuHÁSZ 2016, SÜVEGES et al. 2020).

A vasutak mint vonalas létesítmények egy-egy tájon keresztülhaladva új termőhelykomplexet hoznak létre (PENONE et al. 2012). Bizonyos növényfajok képesek a vasutak mentén húzódó nyílt felszíneken terjeszkedni, mintegy ökológiai terjedési folyosóként használva azokat (WoŁKOWICKI \& BANASZUK 2016, ASCENSÃO \& CAPINHA 2017).

A vasútmenti pionír élőhelyeket gyakran máshonnan a helyszínre szállított talaj, homok, sóder, kőzúzalék borítja, így a rajtuk kialakuló növényzet propagulumforrása lehet az említett nyersanyagok kitermelésének helye. Az említett építőanyagokkal olyan növényeket is behurcolnak az építési területekre, amelyek megtelepedése az adott tájban vagy élőhelyi környezetben egyébként elképzelhetetlen lenne (WILLARD et al. 1990, HugHES et al. 2010, BAUER 2019).

Jelen tanulmányban a vonalas létesítmények közül a vasutak mentén húzódó pionír élóhelyekre és azok jelentőségére szeretnék kitérni, illetve néhány hozzájuk kapcsolódó florisztikai adatot bemutatni.

\section{Anyag és módszer}

A vizsgált élőhelyekre összefoglalóan a vasútmenti pionír élőhely megnevezést alkalmazom. Ebbe beletartoznak a vasúti sínek közvetlen közelében lévő homokos, kavicsos, kőzúzalékos pionír felszínek, melyeken a pionír fajok dominálnak. Ide sorolhatóak a vasúti sínpárok közti kőzúzalékos felszínek, a vasúti töltések rézsűi, illetve a töltések lábánál elhelyezkedő, szintén homokból vagy kavicsból épített alapzati részek.

Az általam vizsgált vasútmenti pionír élőhelyek a Szajol-Karcag-Debrecen, a SzajolKunszentmárton-Szentes és a Pusztapó-Csugar vasútvonalon helyezkednek el. Minden előfordulási adat mellett szögletes zárójelben jelölöm a közép-európai flóratérképezési háló (KEF) kvadrátazonosítóját. A ritka fajokról országos kitekintésben, az elterjedtebbekről elsősorban a Tiszántúlra vonatkozó irodalmi és herbáriumi adatokat tekintem át. A herbáriumi adatokat a Debreceni Egyetem gyüjteményéből (TAKÁcs et al. 2014a, 2015a) tekintettem át. A herbáriumi adatokat az irodalmi adatokhoz hasonló formátumban (gyűjtő neve és évszám megadásával) említem, de a gyűjtőneveket kiskapitális formázás nélkül használom.

Kiemelten foglalkozom az Equisetum ×moorei és a Magyarországon kipusztultnak hitt Galium humifusum vasútmenti előfordulásával, és ezen ritka fajok morfológiai sajátosságait is ismertetem. Figyelembe vettem továbbá néhány flóratérképezési adatot Magyarország edényes növényfajainak online adatbázisából (BARTHA et al. 2021). A fajnevek és a sorszámok KIRÁLY (2009) munkáját követik. 


\section{A Moore-zsurló (Equisetum ×moorei Newman.) morfológiai jellemzői és termőhelyi viszonyai}

Hiányosan ismert, Magyarországon igen ritka faj, pontos hazai elterjedése nem tisztázott. Állandósult hibrid taxon (E. hyemale L. × E. ramosissimum Desf.), könnyen összetéveszthető egyik szülőfajával, a téli zsurlóval.
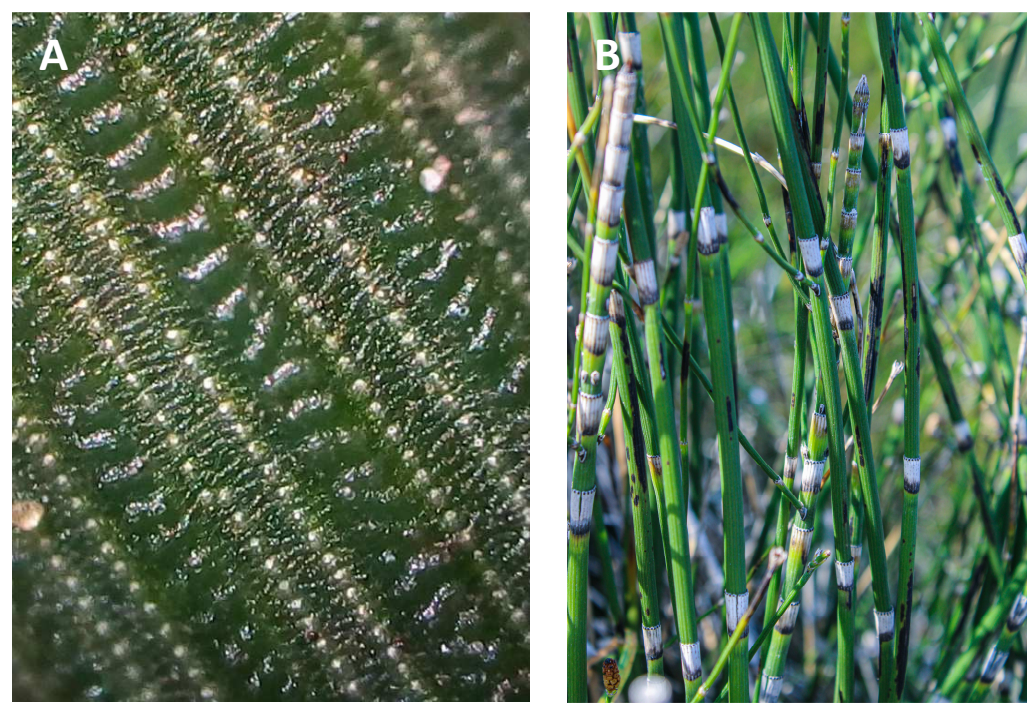

1. ábra A: Kovakeresztszalagok az E. ×moorei szárának bordáin (fénymikroszkópos felvétel, 20× nagyításon); B: E. ×moorei habituskép, Karcag határában (a szerző saját felvételei)

Fig. 1 A: Diatomaceous cross strings on the stem-ribs of $E$. $\times$ moorei

(microscopical photo, 20× enlargement); B: Habit of E. ×moorei, near to Karcag (the author's photos)

A határozó bélyegeket Lubienski munkáiból ismerhetjük meg pontosan. Az egyik legfontosabb megkülönböztető jegye a téli zsurlótól, hogy a levélhüvelyei legalább olyan hosszúak, mint amilyen széles a szár. A levélhüvely fogai korán lehullók, de a legalsó levélhüvelyeken tovább megmaradhatnak (JÁVORKA 1924, LUBIENSKI 2010). Mikromorfológiai jellegzetessége, hogy a szár bordáin kovakeresztszalagok figyelhetőek meg (WINTER \& LUBIENSKI 2012) (1. ábra A). A szár lehet elágazás nélküli vagy elágazó (1. ábra B), utóbbi esetben gyakran csak a hajtás végén, a sporofillumfüzérek alatt ágazik el.

Májustól júniusig a levélhüvelyek fogai még láthatóak, feketék. A levélhüvely ekkor zöldzöldessárga (a fiatal hajtásokon lehet teljesen fekete is), a fogak alatt keskeny fekete keresztszalaggal. A szár ilyenkor még nem ágazik el. Júliusban a levélhüvely világosbarna, általában alsó és felső keresztszalaggal egyaránt. A szár vékony oldalágakat kezd fejleszteni (szabályos örvöket csak ritkán alkot), a sporofillumfüzértől kezdődően, majd a szár többi tagján, a levélhüvelyek alatt. Augusztusban a levélhüvely fehéresbarnává, piszkosfehérré válik. A füzér alatti oldalágak csúcsán gyakran újabb füzérek fejlődnek. A fogak maradványai a hüvely felső részén fekete szalagként maradhatnak meg, míg az alsó fekete szalag később alakul ki. Idővel a fogak teljes lekopásával a felső fekete szalag teljesen eltűnhet. 
KIS (2022): Adatok a vasútmenti pionír élőhelyek flórájához a Tiszántúlon

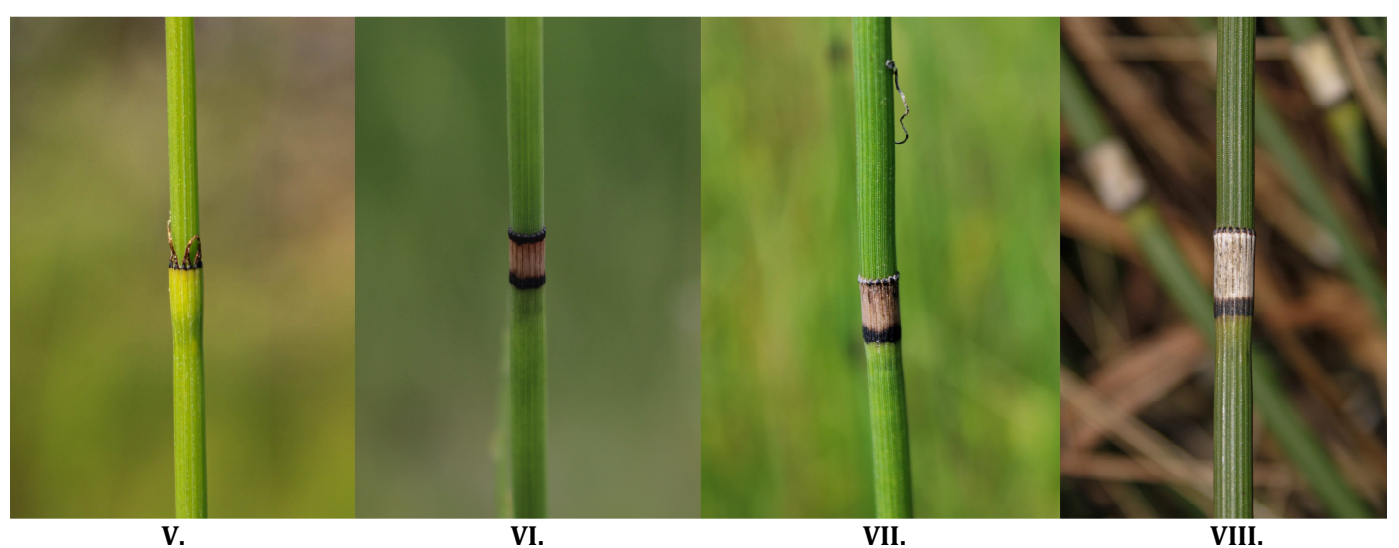

2. ábra A levélhüvely morfológiai változása májustól augusztus végéig

Fig. 2 Change of the leaf sheath from May to August

JÁVORKA (1924) munkájában már megemlíti a levélhüvely alakját mint határozóbélyeget. SIMON (2000) és KIRÁLY (2009) a levélhüvely alakját nem tárgyalják, a hajtást pedig hibásan „általában nem áttelelő”-ként említik. Tapasztalataim szerint részben áttelelő: egyes példányok már november közepén kezdenek elszáradni, míg mások január végén is zöldellőek. Ugyanakkor egyik mű sem említi a mikromorfológiai jellemzőket - ezek fontosságát DEMETER \& LESKU (2021) hangsúlyozták először a hazai szakirodalomban.

KIRÁLY (2009), illetve DEMETER \& LESKU (2021) szerint a fekete keresztszalagok általában csak a levélhüvely felső részén láthatóak. Ezzel szemben megfigyelésem szerint tartósan az alsó fekete keresztszalag marad meg. Augusztus végétől kezdőden egészen az áttelelő példányokig ez figyelhető meg. A fekete keresztszalagok elhelyezkedése időszakosan változó (2. ábra).

Élőhelyeit tekintve összefoglalóan elmondható, hogy nedves, homoktalajú élőhelyeken fordul elő, mely lehet valamilyen pionír felszín, kékperjés láprét vagy erdei aljnövényzet (lásd: Enumeráció).

\section{A heverő galaj (Galium humifusum M. Bieb.) morfológiája}

Magyarországon bizonytalan előfordulású adventív faj: SiMON (2000) kérdőjellel, VIDÉKI (2009) „egykor” megjegyzéssel említi szegedi előfordulását. A fajt mindkét határozó hibásan sárga színű pártával említi, fehér helyett (vö. EHRENDORFER in TuTin 1976). A szár 4 élű, fehéren molyhos, heverő. A hosszabb hajtások vége lehet felegyenesedő. A többi Galium fajtól a talajfelszínre simuló habitusa és rövid, tömött, illatos bugavirágzata jól megkülönbözteti. A többi hazai faj sokkal lazább buga vagy piramis alakú virágzatot fejleszt. 

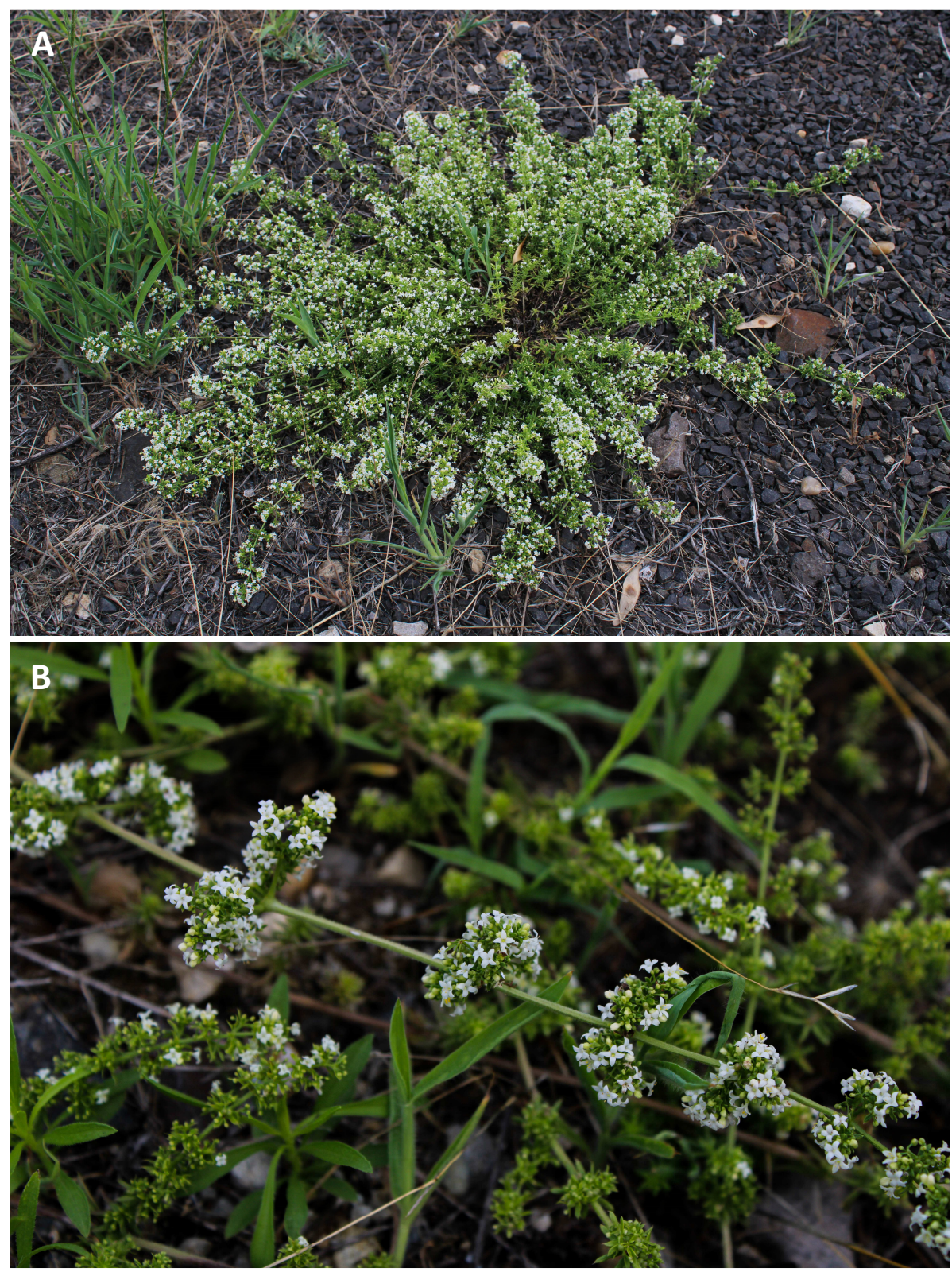

3. ábra A: Habituskép bazaltzúzalékon; B: heverő hajtásrészlet a tömött bugákkal

Fig. 3 A: G. humifusum on broken basalt stone substrate; B: lying sprout fragment with dense inflorescences

\section{Enumeráció}

\section{Equisetum ramosissimum Desf.}

Országosan elterjedt faj, ám a Tiszántúl középső részén nagy területen hiányzik. A Nyírségben gyakori, a Dél-Tiszántúlon szórványosan található meg. Eredetileg évelő homokpusztákon (Festucion vaginatae), pionír rozsnokgyepekben (Brometum tectorum, Bassio lanifoliaeBrometum tectorum), valamint királydinnyésekben (Tribulo-Tragetum) fordul elő. Gyakran 
jelenik meg pionír élőhelyeken, így a vasúti töltéseken. A herbáriumi példányok is sok ilyen előfordulását dokumentálják (,in arenosis aggerum viae ferreae”).

A vizsgált területekhez közel eső, Duna-Tisza közi élőhelyről származó herbáriumi példányok ismertek Bugacról (Vozáry 1952), valamint irodalmi adatok alapján Ceglédről (Szolnoki úti vasúti átjáró kövezete) és Szolnokról (vasútparti kövezésben) (MolNÁR et al. 2018, 2019).

Nyírségi vasúti töltéseken is megtelepszik: ezt herbáriumi példányok is dokumentálják Debrecen (Soó 1947) és Hajdúhadház-Téglás (Soó 1948) határából.

Nem csupán vasúti töltéseken, de más pionír élőhelyeken is megjelenik, így a homokbányákban, például: Orosháza-Gyopáros: homokbánya (Virók 2003), Prügy: homokbánya és környékén (TAKÁCS \& ZsóLYOMI 2011), illetve dunántúli homokbányákban szintén megtalálható (BARINA 2000).

Újabb állományait találtam a Tiszántúl középső részén. A karcagi vasútállomás 2-3., illetve 4-5. vágánya közötti bazaltzúzalékon, továbbá az 5 . vágány melletti bazaltzúzalékos sávban, illetve a vasútállomás keleti felében a sínek között [8691.4]. A vasútállomástól DNy-ra, az egyenirányító telep vasúti átjárójánál szintén megfigyelhető. Ettől tovább DNy-ra, a magyarkai vasúti átjáró mellett jelentős állománya él a töltés mészkőzúzalékán [8791.1]. A vasútállomástól keletre, a Püspökladányi úti vasúti felüljáróinál egy kiterjedt állomány a sínek menti bazaltzúzalékon [8691.4]. Püspökladány határában a Nagy-Kun-lapos melletti vasúti töltés oldalában is jelentős állomány él [8692.3].

További előfordulása Kisújszállás határában, vasúti töltés mentén az Öregerdőtől nyugatra és keletre lévő szakaszon, a kisújszállási vasútállomástól keletre lévő vakvágánynál, illetve Karcag és Kisújszállás között szintén megtalálható [8790.3, 8790.4].

Törökszentmiklóstól keletre, a vasúti töltés mentén hosszan elnyúló állomány figyelhető meg [8889.1].

Szajolon a Rózsa Ferenc utcai vasúti átjárótól keletre kiterjedt állomány található a vasúti töltés szélén [8887.2]. Szajoltól délkeletre Tiszatenyő határában a vasúti töltés mentén több foltban is előfordul [8888.3].

Megjelenik továbbá a Püspökladány-Hajdúszoboszló-Debrecen vasútvonal több pontján: Püspökladánytól keletre [8692.4, 8693.3], a kabai vasútállomástól délnyugatra [8693.2], Hajdúszoboszlótól délnyugatra [8594.3, 8694,1], Ebes határában több ponton a vasúti töltésben [8594.2, 8595.1], valamint Ebes és Debrecen között [8595.1].

16. Equisetum $\times$ moorei Newman. (E. hyemale $\times$ E. ramosissimum)

Országosan ritka elterjedésú taxon. Nehéz azonosíthatósága miatt kevés biztos adata ismert.

A Dunántúlról és a Duna mentéről Győrzámoly (Polgár 1915), Pomáz (Traumann 1918), Oroszlány (Boros 1937), Dunakeszi (Boros 1939), Szigetújfalu (Kárpáti 1943), Göd (Soó 1948) és Nyirád (Sramkó 2003) határából vannak herbáriumi példányai a DE gyüjteményben. Győrzámoly, illetve Győr határban anyagnyerő gödrökben, valamint rekettyefüzes alatt (SCHMIDT 2015), a Gödi-lápréten kékperjésben fordul elő (Szollát et al. 2007). BARINA (2000) munkája szerint a dunántúli homokbányában sokfelé megtalálható. Ezen homokbányák a taxon természetes élőhelyeihez, a Duna és a Dráva árteréhez közel helyezkednek el.

A Duna-Tisza közén megtalálható a Solti-síkon, Soltszentimre határában, ahol az ott elterülő homoki láp- és sztyepprét mozaikokban figyelhető meg (BÁTORI et al. 2014). Az ócsai Öreg-turjánon kékperjés lápfoltokban fordul elő (CSÁKY 2018).

A Börzsöny lábánál Érsekvadkert határában, Göröc-pusztán, felhagyott szőlőben is megfigyelték (MALATINSZKY et al. 2014). 
Herbáriumi adatok alapján ismert a Nyírségből is. Megtalálható Sáránd határában nemesnyaras aljnövényzetében (Süveges 2018), a hajdúbagosi Bagosi-erdőben (Soó 1933), Debrecen-Bocskaikert környékén (Soó 1934), a Debrecen határában lévő Nagyerdőben (Siroki 1947), illetve az Apafai erdőben (Felföldy 1939), Hosszúpályi határában (Soó 1933), a Bagaméri-erdőben (Soó 1933), a nyírlugosi Külsőguth-erdőben (Soó 1947) és Vámospércs (Matus 2012) határában. A Nyírségben leggyakrabban árnyas erdők aljnövényzetéből írják le a gyűjtők. Újabban a Nyírségre vonatkozó előfordulási adatokat DEMETER \& LESKU (2021) összegzik.

Az Equisetum ×moorei első, új adata a Tiszántúl középső részéről, a Karcag melletti Püspökladányi úti vasúti felüljáró mellől származik. A felüljárótól egészen a Karcagi-(1.sz.)főcsatornáig megtalálható, ahol a vasúti töltés alapzatának építéséhez használt homokon, mintegy 600 méteres szakaszon több száz töves állományát figyeltem meg [8691.4]. A töltésen olyan pionír homoki gyepekre, illetve löszgyepekre jellemző fajok jelentek meg, mint a Salsola kali, Chondrilla juncea, Rumex acetosella, Bromus tectorum, Reseda lutea, Verbascum phlomoides, Echium vulgare, Tribulus terrestris, Oenothera biennis, Tragus racemosus, Scabiosa ochroleuca, Melica transsilvanica, Anchusa officinalis, Centaurea stoebe, Trifolium arvense, Euphorbia cyparissias, Saponaria officinalis, Vicia villosa és a Linaria biebersteinii. Míg a töltésmenti talpárokban és a nedvesebb mélyedésekben Equisetum arvense-vel együtt fordul elő, a vasúti töltés felső, szárazabb részein Equisetum ramosissimum-mal együtt figyelhető meg.

Az említett területtől keletre, Karcag és Püspökladány között szintén jelentős állományokat, sűrű „kefebozótokat” alkot a vasúti töltés szubballasztikus mészkőzúzalékán, a homokalapzaton és a talpárokban, egészen az apavárai vasúti hídig (2. ábra). A püspökladányi Nagy-Kun-lapos melletti vasúti töltésen szintén megjelenik [8692.3].

Tovább keletfelé szintén előfordul Püspökladány belterületén több foltban, a Farkasszigeti úti és a Kiss Ferenc utcai vasúti átkelő között, illetve utóbbitól keletre, az egykori fatelítő telep melletti vasútvonal mentén egészen a Baross utcai vasúti felüljáróig [8692.4]. A karcagi állományhoz hasonlóan a vasúti töltés homokalapzatán fordul elő nagy számban. Kísérő fajok: Chondrilla juncea, Salsola kali, Tribulus terrestris, Euphorbia cyparissias, Echium vulgare, Setaria pumila, Conyza canadensis, Oenothera biennis, Saponaria officinalis, Solidago gigantea, Reseda lutea, Aster sedifolius, Verbascum phlomoides.

Püspökladánytól ÉK-re egybefüggő, nagy állományai nem figyelhetőek meg, viszont kisebb állományokban (gyakran csupán szálanként) megtalálható Ebestől DNy-ra a vasúti töltésen, valamint a töltésmenti talpárokban [8594.2].

Karcagtól délnyugatra, nagyobb állományok figyelhetőek meg a Bócsai legelő melletti vasúti töltéseken, az egykori 4-es számú fơút felüljárójától keletre, illetve attól nyugatra, a Karcagi puszta vasúti megállóhelynél [8791.1].

Kisújszállás keleti szélén, a Malom utcai vasúti átkelőnél a vasúti töltésen [8790.4], illetve a vasútállomástól nyugatra a Bittnerfalu melletti vasútszakasz töltésében szintén megtalálható nagyobb foltokban. Innen nyugatra lévő, az Öregerdőn áthaladó vasúti sínpár töltésében ugyancsak jelentős állomány található [8790.3].

Örményes határában a Nagykunsági öntöző főcsatorna vasúti hídjától nyugatra két nagyobb állomány került elő a vasúti töltésen [8789.4, 8889.2].

Törökszentmiklóstól nyugatra, Szajol irányában a vasúti töltésen egy nagykiterjedésủ állományt alkot [8888.1]. 
Az Equisetum ×moorei elsősorban a vasúti töltések homokkal feltöltött alapzatán, illetve a töltések melletti talpárokban figyelhető meg, ugyanakkor szálanként, kisebb állományokban megjelenik bazaltzúzalékon is. A talpárokhoz közeledve egyre sűrűbbé válik az állomány.

\section{Salsola kali L.}

A Tiszántúlon szórványos-ritka elterjedésű faj. Pionír élőhelyeken jelenik meg, mint a vasúti töltések és az anyagnyerő bányák. A Dél-Tiszántúlon a Szarvas-OrosházaHódmezővásárhely vasútvonal mentén jelentős állományokat alkot, továbbá felhagyott homokbányában: Szarvas, Szegvár, Fábiánsebestyén és Tiszaföldvár határában (TóTH 2003).

Karcagon a Püspökladányi úti vasúti felüljáró közelében, vasúti töltés homokján [8691.4], valamint Püspökladány belterületén a Kiss Ferenc utcai vasúti átkelőnél [8692.4] kavicsoskőzúzalékos pionír élőhelyen találtam meg.

364. Petrorhagia prolifera (L.) H.W. Ball et Heywood

A Tiszántúlon ritka, a Nyírségben gyakori előfordulású. Irodalmi adatai ismertek Poroszló, Tiszafüred, Karcag és Hortobágy határából (Soó \& MÁTHÉ 1938). Flóratérképezési adatai ismertek továbbá Kisújszállás és Vésztő határából (BARTHA et al. 2021).

Vasúti töltések mellől származó adatai ismertek például Gyomaendrődről, ahol használaton kívüli vasúti töltés mellett került elő (TóTH 2003).

Új előfordulási adata származik a karcagi vasútállomásról, ahol az 5. vágány melletti kavicsos-homokos pionír felszínen jelenik meg [8691.4]. Néhány töves állományát észleltem Püspökladánytól nyugatra, a vasúti átkelő homokján [8692.3]. Jelentős állománya került elő továbbá Kétpó határából, Pusztapó vasúti megállóhely állomása mellett, szintén kavicsos pionír felszínen [8988.2].

601. Lepidium densiflorum Schrad.

Észak-amerikai eredetű adventív faj. Észak-Magyarországon sok helyen elterjedt vasutak és műutak mentén (MolNÁR \& JUHÁSz 2016, MolNÁR et al. 2018). A Tiszántúlon elsősorban Debrecen környékéről ismert. Herbáriumi adatai ismertek Debrecenből (Soó 1946, Simon 1947, Siroki 1949), Konyárról (Soó 1949) és Bátorligetből (Soó 1953). Debrecen belterületén is megfigyelték már (TAKÁCS \& LöKI 2015).

Újabb előfordulása a karcagi és a kisújszállási vasútállomás mellett került elő [8691.4, 8790.4], ahol a vasútmenti kavicsos felszínen tömegesen jelenik meg.

\section{Euphorbia maculata L.}

Észak-amerikai eredetű adventív faj, amely valószínűleg a dísznövénykereskedelem révén városi környezetben egyre elterjedtebb járdák repedéseiben, térkövezések réseiben (vö. TAKÁcs et al. 2020). Felfedezhető ugyanakkor a vasútállomások pionír, kavicsos felszínein is, mint a füzesabonyi és a salgótarjáni vasútállomás környezetében, taposott gyomnövényzetben (CSIKY \& KóBOR 2001, MOLNÁR et al. 2016).

Püspökladányban a vasútállomás $1 \mathrm{~A}$ vágánya melletti mezsgyében, sóderes-kavicsos talajon, illetve a térkövezés rései között került elő [8692.4].

\section{Lycopsis arvenisis $\mathrm{L}$.}

Magyarországon ritka elterjedésű gyomfaj. Érdekesség, hogy Soó \& MátHÉ (1938) művében még nem említi a Tiszántúlról, illetve korábbi művekből sem ismert innen.

Első tiszántúli adata egy herbáriumi példány Újfehértóról (Gondola 1967). Legtöbb alföldi adata kifejezetten a vasúti töltésekről származik. Vasúti töltésekről, vasúti kőzúzalékról származó irodalmi adatait Gyomaendrődről, Fegyvernek-Örményes állomásról, Hajdúnánás- 
Tedejről, Karcag-Apaváráról, Hortobágy-Kónya vasúti megállóhelyről és Hortobágy vasútállomásáról ismerjük (SZUjKó-LACZA 1982, MoLNÁR V. et al. 2000, TAKÁCS et al. 2014b, LUKÁCS et al. 2017, MolNÁR et al. 2017, 2019). A Tiszántúlon emellett más, homoktalajú élóhelyeken is megtalálható (LuKÁcs et al. 2017). A Duna-Tisza közén homoki parlagokon jelenik meg (KIRÁLY \& KIRÁLY 2018). A Dunántúlon részben Tatabánya környékére (Tatabánya-Bánhida, Környebánya, Vértessomló) koncentrálódik a faj elterjedése (PINKE et al. 2003, 2006). Néha pionír bazaltfelszíneken, illetve homokbányákban jelenik meg (Csokvaomány: az Upponyihegység homokbányái - MALATINSZKY 2002; a tihanyi Óvár délnyugati lábánál, bazalttufán BAUER 2010).

Ezzel együtt megjelenik más antropogén, pionír felszíneken, mint a tiszavasvári alkaloidagyár közelében (TAKÁCS et al. 2014b), a debreceni nagyállomás előtti járdaszigeten (TAKÁCS \& LÖKI 2015), Debrecen-Pallagon homokbányában (Siroki 1973), Hejőpapi határában lévő kavicsbánya mellett (SÜVEGES et al. 2020), valamint Igrici M3-as autópályapihenőhelyénél (Süveges K. szóbeli közlése).

Karcagon a Püspökladányi úti vasúti felüljárótól nyugatra, közvetlenül a sínek melletti bazaltzúzalékon [8691.4], illetve a felüljárótól keletre a vasúti töltésen nagyjából 10 töves állományt találtam. Karcagtól keletre, az apavárai vasúti hídnál felfedett állomány LUKÁCS et al. (2017) szerint a pályakarbantartási munkálatok során kipusztult. Ezen kipusztultnak hitt állományt találtam meg újra 2020. június 1-én. A vasúti híd melletti töltésen közel 20 töves, míg a vasúti híd mellett a Hortobágy-Berettyó gátjának kavicsos felszínén kb. 50 töves állományt fedeztem fel [8692.3]. Ezen kívül az apavárai állománytól nyugatra lévő vasúti átjárónál szintén egy jelentős állomány került elő [8691.4].

1727. Galium humifusum M. Bieb.

A Fekete-tenger vidékétől (Románia, Bulgária, Görögország, Törökország) egészen Mongóliáig előfordul. Hazánkhoz legközelebb Romániában az Észak-Dobrudzsai-hátságon fordul elő, ahol az erősen kötött talajok indikátorfaja (MARUȘcA et al. 2020). Ukrajnában a sztyeppövezetben a Leymo ramosi-Stipetum lessingianae társulásban fordul elő (VYNOKUROV 2021).

Magyarországon az első példányokat Tímár Lajos gyűjtötte 1947-ben Szegeden, a Körtöltés Rókus városrésznél lévő szakaszán. Jeanplong József herbáriumi gyűjteményéből szintén ismerjük, aki 1951-ben szintén Szegeden gyüjtötte (vö. BALOGH \& KULCSÁR 2013). Ezen kívül más előfordulási adata nem ismert.

Új termőhelye Törökszentmiklóson került elő [8888.1]. A vasútállomástól keletre, a vasúti sínek és a parkoló közötti keskeny, kavicsos talajú, pionír élőhelyen találtam meg 2021. július 20 -án. Nem csak itt, de a sínek melletti bazaltzúzalékon is megjelenik. Kísérő fajok: Conyza canadensis, Digitaria sanguinalis, Polygonum aviculare, Vulpia myuros, Tragus racemosus.

\section{Plantago indica $\mathrm{L}$.}

A Tiszántúlon alig néhány flóratérképezési adata ismert (feltehetően másodlagos élőhelyekről). Karcag mellett vasút mentén (Gulyás 2009), illetve Besenyszög határában pionír felszíneken került elő (MoLnÁR et al. 2018).

A Nyírségben némileg elterjedtebb: Debrecenből (Felföldy 1937), Hajdúbagosról (Soó 1937), a Bagosi-legelőről, a Monostorpályi-legelőről és a Létai-legelőről Létavértes határából (MATUS et al. 2019) ismert.

Debrecenben a vasútállomás épületétől DK-re eső irodaépületek előtt, a sínek melletti homokos-kavicsos talajon jelentős állománya került elő újonnan [8495.4]. 


\section{Chondrilla juncea $\mathrm{L}$.}

A Tiszától nyugatra (elsősorban a homokvidékeken) és a Nyírség területén gyakori, a Tiszántúlon ritka. Vasutak mentén jelenik meg Cegléden (Szolnoki úti vasúti átjáró), Szolnokon, valamint Hortobágy-Kónya vasúti megállóhely (MoLNÁr et al. 2017, 2019).

Újonnan került elő Karcagon, a vasútállomás 5. vágánya melletti mezsgyében egy jelentős állománya, illetve a Püspökladányi úti vasúti felüljárótól keletre, vasúti mezsgye homokjában [8691.4]. Püspökladányban az egykori fatelítő telep melletti vasútszakasz mentén, a sínek mellett bazaltzúzalékon [8692.4], valamint Püspökladánytól nyugatra, Ágota-puszta déli részén lévő vasúti átkelőnél, a vasúti töltés homokalapzatán [8692.3]. Ebestől északkeletre szintén megtalálható egy mellékvágány mentán [8595.1]. Kisújszállástól nyugatra, az Öregerdő mellett húzódó vasúti töltés mentén jelentős állományok, illetve a 4201-es mellékút vasúti felüljárójánál [8790.3]. Egy kisebb állományt találtam továbbá a tiszatenyői vasútállomáson [8888.3].

\section{Crepis rhoeadifolia Bieb.}

Országszerte elterjedt faj, mely a Tiszántúlon ritka. Szolnokon már korábban is ismert volt vasútmenti pionír élőhelyről (MoLnÁR et al. 2019). Püspökladány belterületéről, a Kiss Ferenc utcai vasúti átkelőnél, a vakvágány melletti pionír felszínről szintén ismert (FEHÉR 2014). Jelentős, új állományát találtam meg Püspökladánytól nyugatra lévő vasúti átkelőnél, homokon [8692.3], valamint egy néhány töves állományt az ebesi vasútállomás mellett, pionír kavicsos élőhelyen [8594.2].

2322. Vulpia myuros (L.) C.C. Gmel.

Régi herbáriumi adatai nem ismertek a Tiszántúlról. Első említése Ohatról származik (Soó \& MÁTHÉ 1938). Az ország keleti felében ritka, a Dél-Nyírségben (elsősorban Debrecen környékén) szórványos. Jelentős állományai élnek Debrecen mellett a sámsoni úti katonai gyakorlótéren, illetve Martinka határában, mindkét esetben nyílt homoki élőhelyeken (MoLnÁR V. et al. 2000). A faj eredetileg mészkerülő efemer növényzetben (Thero-Airion) fordul elő. Számos helyen előkerült Debrecen belterületén is (TAKÁcs \& LöKI 2015).

Számos adata származik vonalas létesítmények menti pionír élőhelyekről (utak mellől és vasúti töltésekről). Így megjelenik például Szolnokon egy vasúti töltésen, a kétegyházi vasútállomáson, a putnoki és hatvani vasútállomáson is (vö. MoLNÁR et al. 2016, 2019). Valószínúleg sokkal elterjedtebb, mint ahogy azt flóratérképezési adatai mutatják.

Újabb előfordulása került elő a karcagi vasútállomás mellől kavicsos-homokos pionír felszínről, valamint attól keletre vasúti töltésről [8691.4]. Szintén megtalálható Karcagtól délnyugatra a vasúti töltés több pontján, illetve Karcagtól keletre az apavárai vasúti hídnál [8791.2, 8791.1, 8692.3]. A kisújszállási és törökszentmiklósi vasútállomás közelében jelenik meg, mindkét esetben kavicsos-kőzúzalékos felszínen fordul elő [8790.4, 8888.1]. Továbbá Püspökladánytól nyugatra lévő vasúti átkelőknél [8692.3], az ebesi vasútállomástól délnyugatra a vasúti töltés több pontján [8594.2], Kétpó-Pusztapó vasúti megállóhely mellól, vasútmenti pionír kavicsos-kőzúzalékos élőhelyen került elő [8988.2]. Vasútállomások közelében, vasútmenti kavicsos pionír élőhelyeken (sínek mentén, sínek között vagy a vasúti töltés oldalán) találtam meg továbbá Szajol [8887.2], Tiszatenyő [8888.3], Kengyel [8988.1], Martfú [8987.4], Szentes-Hékéd és Szentes [9387.2] vasútállomásain és megállóhelyein.

2499. Tragus racemosus (L.) All.

Trópusi eredetű, adventív faj. A Duna-Tisza közén, valamint az ország nyugati és északi felében számos helyen elterjedt, ugyanakkor a Tiszántúlon kevés előfordulása ismert. Sok esetben jelenik meg vasútállomások közelében vagy vasúti töltéseken (Alföld: Szeged, Cegléd, 
Abony, Szolnok, Hajdúnánás; Észak-Magyarország: Tárnok, Eger, Vámosgyörk, Borsodkisfalud, Sárospatak; Dunántúl: Székesfehérvár, Kóny, Bősárkány) (MolNÁr 2001, TAKÁcs et al. 2015b, MoLnÁr et al. 2018, 2019).

Debrecenben a vasútállomás több pontján (térkő és a sínek között), valamint a Nagyállomás előtti villamosforduló járdaszigeteiben találtam meg [8495.4]. Az ebesi vasútállomáson szintén megtalálható egy kisebb állománya [8594.2]. Ezenkívül előkerült Karcagon, a vasútállomástól keletre az apavárai vasúti hídig [8691.4], illetve Karcagtól délnyugatra több ponton a vasúti töltésen [8791.2, 8791.1]. Püspökladánytól nyugatra szintén megtalálható a vasúti töltésen [8692.3]. Vasútállomásokon jelenik meg továbbá Kisújszálláson [8790.4], Törökszentmiklóson [8888.1], Szajolon [8887.2], Tiszatenyőn a vasútállomásnál, illetve Tiszatenyőtől északnyugatra végig a vasúti töltés mentén [8888.3]. Továbbá Martfün [8987.4], Kunszentmártonon [9187.4], Nagytőkén [9287.2], Szentes-Hékéd megállón [9387.2] és Szentesen [9387.2] is előfordul a vasútmenti pionír élőhelyekben.

\section{Diszkusszió}

Az Equisetum ×moorei esetében felmerül a hibridsterilitás lehetősége, amit különböző szerzők eltérően ítélnek meg (KRAHULEC et al. 1995, HusBY 2013), azonban vegetatívan a többi zsurlófajhoz hasonlóan jól szaporodik. Ezáltal nem ítélhető meg, hogy emberi közvetítés nélkül milyen módon és milyen távolságra képes terjeszkedni (spórával szél útján hosszútávon, vagy csak vegetatív sarjakkal rövidtávon).

Törökszentmiklós és Püspökladány között a faj nagy összefüggő állományokat alkot. A Szajol-Püspökladány közötti vasútvonal korszerűsítése 2011-2015 között zajlott, ezen belül a Karcag-Apavára-Püspökladány vasúti szakaszt 2012-ben újították (FüLÖP \& SzABó 2016). Feltehetően ezen felújítások során szóródhatott szét az Equisetum ×moorei propaguluma, majd vegetatívan szaporodva sűrủ állományokat hozott létre Törökszentmiklós és Püspökladány között. A Püspökladánytól keletre lévő nagykiterjedésű állományok hiányát feltehetően a késői pályafelújítási munkálatok, pályakarbantartás okozza. A faj nyírségi elterjedtségére és nyírségi vasútvonalak menti megtelepedéseire való tekintettel (vö. DEMETER \& LESKU 2021) valószínű, hogy a vizsgált vasútvonalat is ebből az irányból kolonizálta.

A vasúti töltések, illetve a töltés melletti talpárkok hasonló termőhelyi viszonyokat teremtenek, mint a kavics- és homokbányák mélyedései. A homok alapkőzetű kékperjés lápréteken, a nyírségi árnyas erdőkben, illetve a Duna és a Dráva ártéri erdeiben valószínúleg szintén a felnyíló, pionír felszínekre képes betelepülni. Vasúti töltéseken északi kitettségü oldalakon sokkal gyakrabban figyelhető meg, mint a déli oldalon. Bár a vasúti töltések alapvetően kedvezőtlen, száraz termőhelyet kínálnak a zsurlófajok (E. ×moorei, E. ramosissimum, E. arvense) számára, ha azonban a töltés alatt valamilyen vízzáró réteg húzódik, mélyre hatoló rizómájuk segítségével képesek elérni a talaj mélyebb rétegeiben lévő vizet (DANERT et al. 1980). A rézsűk északi oldalán és talpárokban való megjelenése összhangban van BoRHIDI (1993) jelzéseivel, miszerint az E. × moorei nedvességjelző növény (WB=8).

Az E. ×moorei és más hibrid zsurlótaxonok másodlagos élőhelyeken (vasúti kőzúzalékon, kavicsbányákban) való terjedésére LUBIENSKI et al. (2011) is felhívja a figyelmet a Felső-Rajna vidékén. München külterületén régi, bazaltos-kavicsos vasúti töltéseken fordul elő (DicKORÉ \& SPRINGER 2011). MELZER \& BARTA (2001) szerint a Bécsi-medencében egyaránt megtalálható a kavics- és homokbányákban. Lengyelország déli és keleti részéről KALINOWSKI et al. (2016) említi vasúti töltésekről és vasútállomások közelében (Bukowno: vasútállomás, Platerów \& 
Niemojki: vasúti töltésen). Ismerteti továbbá HÁJEK et al. (2005) a bolgár-görög határvidékről, a Kulata közelében, ahol a vasúti sínek homoktöltésén bukkant fel. A szlovák irodalomban a vasúti töltések mentén meglévő Moore-zsurló állományokat önálló társulásként, Dauco-Equisetetum ×moorei (ZLINSKÁ 1995) néven írták le Pozsony környékéről és a felvidéki Erdőhátról. Bár jelen esetben hasonlóan a vasúti töltésre korlátozódik az E. ×moorei előfordulása, a társulásnál leírt kísérőfajok eltérőek.

A Lycopsis arvensis megfigyelt populációi elszigetelten helyezkednek el egymástól. Országos kitekintésben érdekes, hogy míg a Dunántúlon szántóföldi gyomnövényként jelenik meg (PINKE \& PÁL 2001, TóTH 2018) addig a Tiszántúlon többségében antropogén felszíneken (vasúti töltések, kavicsfelszínek, építési területek) figyelhető meg. Eredetileg feltehetően zavartabb, nyílt homoki gyepeken fordulhatott elő. Az igen változatos élőhelyeket összekapcsoló ökológiai tényező a laza, homokos vagy kavicsos talaj. Egyes esetekben megjelenik frissen felújított, illetve urbanizált területeken is (TAKÁCS \& LÖKI 2015), valamint egyéb pionír élőhelyeken is, mint a kavicsbányák (BZDon 2009, SüvEGES et al. 2020).

Egyes homokgyepi fajok valószínúleg a kiterjedt kiskunsági és nyírségi állományokból képesek kolonizálni a vasúti töltések homokalapzatait és ezeken mintegy tényleges ökológiai folyósó mentén terjeszkedni, olyan tájakon keresztül, amelyekben egyébként nem lenne adott a tömeges megtelepedésük lehetősége. Ilyen például az Equisetum ramosissimum, Chondrilla juncea, a Salsola kali és a Crepis rhoeadifolia.

Ez a jelenség különösen jól megfigyelhető az Equisetum ramosissimum esetében, melynek állományai Szolnoktól nyugatra is nyomon követhetőek az Abony-Cegléd-Monor-Üllő- Kőbánya-Kispest vasútvonalon is. Nem csupán a Tiszántúlon jelenik meg a vasúti töltések mentén, hanem a Duna-Tisza közének nem homok alapkőzetű területein is (pl. Kiskunsági löszöshát). Így a Csongrád-Kiskunfélegyháza vasútvonal több pontján: Csongrád-Kónyaszék [9386.1], Csongrád-Kettőshalom megállóhely közelében, bazaltzúzalékon [9286.4]. Ezen állományok aztán tovább kolonizálva a vasúti töltéseket átjuthatnak a Tiszántúlra.

A vasúti homoktöltések termőhelyi adottságai igen hasonlóak a száraz, nyílt homoki gyepekéhez, így egy összeköttetésként funkcionálnak a Duna-Tisza köze és a Nyírség homokvidékei között. A vasúton való terjeszkedésre kiváló példa továbbá a Tribulus terrestris elterjedése (DANCZA et al. 2002). Szintén kifejezetten homokgyepi faj a Plantago indica, mely nem csupán a debreceni vasútállomáson jelenik meg, hanem a Tiszántúl közepéről, KarcagPüspökladány közötti vasúti pálya mellől is ismert (Gulyás 2009). A Petrorhagia prolifera eredetileg a pionír homoki és sziklagyepek faja, ugyanakkor az előbb említett fajokhoz hasonlóan megjelenik a vasútmenti pionír élőhelyeken.

Az adventív fajok terjeszkedésében különösen nagy szerepet játszik ezen ökológiai folyósók megléte. A potenciálisan özöngyomként terjedő Tragus racemosus jól terjed a vasútmenti pionír élőhelyeken keresztül, ugyanakkor az autóutak mentén is hasonlóan képes újabb területeket kolonizálni. A Duna-Tisza közi területeken megjelenik a vonalas létesítményektől távol is. Feltehetően sokkal elterjedtebb a vasutak és műutak mentén a Tiszántúlon, mint azt az eddig dokumentált előfordulásai sugallják (vö. BARTHA et al. 2021).

Az Euphorbia maculata özöngyomként való terjedése bár nem kimondottan a vasúti töltésekhez köthető, ugyanakkor megjelenik a vasútállomások díszkövezetének réseiben és más, homokos-kavicsos felszíneken. Feltehetőleg kertészeti gyomként az állomásokon kihelyezett dísznövényekkel terjed (vö. TAKÁcs et al. 2020), de az utasforgalom is szerepet játszhat a terjesztésében.

A későbbiekben a Cenchrus incertus potenciális megjelenése és újabb állományainak felfedezése várható. Állományai már a Duna-Tisza közéről kiindulva megjelentek Szolnok, Me- 
zőtúr, Debrecen és Nyíregyháza vasútállomásain (MolNÁR 2001, MoLNÁr et al. 2018, 2019). A Szolnok-Debrecen között viszont még nincs ismert adata.

Hasonlóan a vonalas létesítmények (vasutak, autóutak) mentén elterjedt az adventív Senecio inaequidens, mely a pionír felszínekről kilépve képes más területeket is kolonizálni (HASZONITS \& SCHMIDT 2018).

A tiszántúli vasútmenti élőhelyeket természetesen a tájhonos vegetáció pionír jellegű (de akár évelő) képviselői is kolonizálják, melyek propagulumforrásai a környező mezsgyék. Ilyen fajok például: Aegylops cylindrica, Astragalus glycyphyllos, Centaurea scabiosa ssp. scabiosa, Cephalaria transsylvanica, Melica transsilvanica, Potentilla recta, Scabiosa ochroleu$c a$.
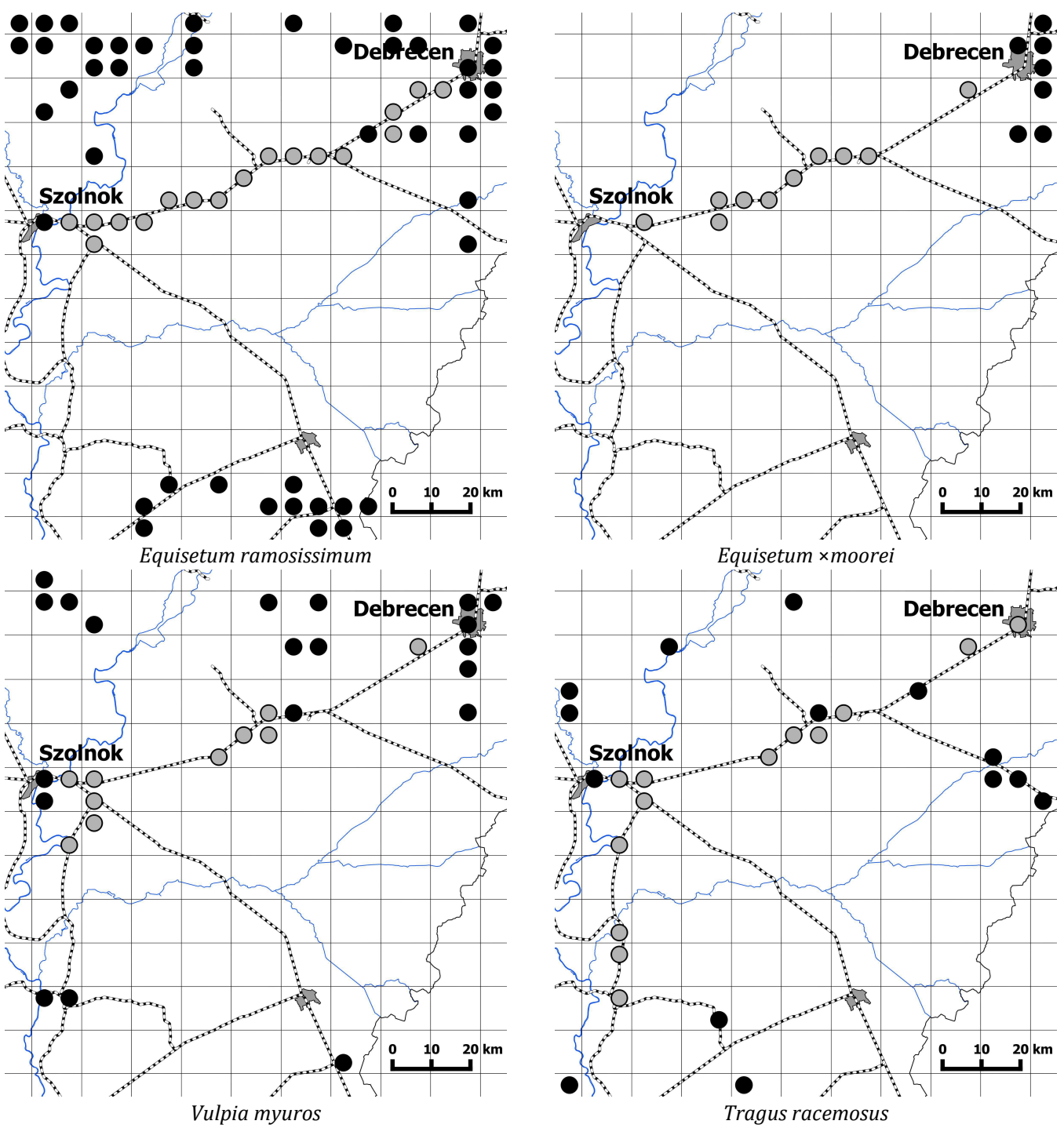

4. ábra Négy faj elterjedése a vizsgált területen; a fekete körök Magyarország flóratérképezési adatbázisból, a szürkék az itt közölt adatokból származnak

Fig. 4 Distribution maps of four species in the study area; black circles represent data from the Atlas Florae Hungariae, grey circles represent new data 


\section{Konklúziók}

A vasútmenti pionír élőhelyek kiemelt szerepet játszanak egyes ritka, valamint adventív (inváziós) fajok terjedésében. Egyes nem tájhonos (lokálisan adventív) homokgyepi fajok képesek a vasúti töltések mentén terjeszkedni. Töltéseken megjelenő fajok ökológiai folyósóként használják ezen keskeny élőhelysávokat.

\section{Köszönetnyilvánítás}

Ezúton is szeretném megköszönni Takács Attilának a Debreceni Egyetem herbáriumi gyűjteményeiben nyújtott segítségét, valamint Demeter Lászlónak az irodalmi ajánlást és a személyes tapasztalatokat.

\section{Irodalom}

AsCENSÃo F. \& CAPINHA C. (2017): Aliens on the move: Transportation networks and non-native species. In: Borda-de-Água L., Barrientos R., Beja P. \& Pereira H. M. (eds), Railway Ecology. Springer, pp. 65-80.

BALOGH L. \& KulCSÁR L. (2013): Jeanplong József (1919-2006) herbáriuma a szombathelyi Savaria Múzeumban. - Savaria - A Vas Megyei Múzeumok Értesítóje 36: 23-51.

BARINA Z. (2000): Felhagyott homokbányák florisztikai vizsgálata I. - Kitaibelia 5(2): 313-318.

BARTHA D., BÁN M., SCHMidT D. \& TiboRCz V. (2021): Magyarország edényes növényfajainak online adatbázisa (http://floraatlasz.uni-sopron.hu). - Soproni Egyetem, Erdőmérnöki Kar, Növénytani és Természetvédelmi Intézet. (hozzáférés: 2021. 08. 24.)

BAUER N. (2010): Adatok a Balaton-felvidék flórájának ismeretéhez IV. - Kitaibelia 15(1-2): 53-63.

BAUER N. (2019): Útépítési nyersanyaggal behurcolt dolomitsziklagyep-fajok tömeges megjelenése Kecskeméten. - Kitaibelia 24: 258.

BÁtori Z., ERdőS L., CSEH V., TÖLGYesi Cs. \& ARADi E. (2014): Adatok Magyarország flórájához és vegetációjához I. - Kitaibelia 19(1): 89-104.

BorHIDI A. (1995): Social behaviour types, the naturalness and relative indicator values of the higher plants in the Hungarian Flora. - Acta Botanica Hungarica 39: 97-12.

BzDON G. (2009): Floristic diversity of gravel-pits of the Siedlce Plateau - an analysis of the flora. Annales Universitatis Mariae Curie-Skłodowska, Biologia 64(1): 35-66.

Csathó A. I. (2009): A mezsgyék természetvédelmi jelentősége és védelmük időszerűsége. Természetvédelmi Közlemények 15: 171-181.

Csathó A. I. \& CsAthó A. J. (2010): A dombegyházi Battonyai út egy védelmet érdemlő mezsgyeszakaszának flórája. - Crisicum 6: 33-57.

CsÁKY P. (2018): A turjánvidék északi részének florisztikai szempontból jelentős növényfajai. - Rosalia 10: $145-252$.

CSIKY J. \& Ко́воR I. (2001): Újabb adatok Nógrád-Gömöri bazaltvidék (Karancs, Medves, Cernová Vrchovina) flórájához. - Kitaibelia 6(2): 281-289.

DANCZA I., PÁL R. \& CSIKY J. (2002): Zönologische Untersuchungen über die auf Bahngeländen vorkommenden Tribulus terrestris-Unkrautgesellschaften in Ungarn. - Zeitschrift für Pflanzenkrankheiten und Pflanzenschutz 18: 159-166.

DANERT S., FukAReK F., HANElt P. \& Helm J. (szerk.) (1980): Uránia növényvilág. Magasabbrendű növények I. - Gondolat Kiadó, Budapest, pp. 64-69.

Demeter L. \& LESKu B. (2021): Az Equisetum × moorei és E. hyemale nyírségi elterjedésének kritikai áttekintése. - Kitaibelia 26(2): 131-144.

Denisow B., WRZESiEŃ M., MAMChUR Z. \& ChuBA M. (2017): Invasive flora within urban railway areas: a case study from Lublin (Poland) and Lviv (Ukraine). - Acta Agrobotanica 70 (4): 1-14.

DickorÉ M. B. \& SPRINGER S. (2011): Neues zur Flora von München. - Berichte der Bayerischen Botanischen Gesellschaft 81: 79-108.

Ehrendorfer F. (1976): Galium L. - In: Tutin T. G. et al. (eds), Flora Europaea vol. 4., Cambridge University Press, Cambridge, pp. 14-36. 
FEHÉR S. (2014): Vasúti jövés-menés, avagy homoki vegetáció egy „háromföldi” vasútállomáson. - In: То́тн A. (szerk.), A tájkutatás szolgálatában. 40 éves a Hortobágyi Természetvédelmi Kutatótábor. Alföldkutatásért Alapítvány, Kisújszállás, pp. 261-273.

FÜLÖP Z. \& SZABó I. (2016): A Szajol-Püspökladány vonalszakasz korszerűsítése 2011 és 2015 között, az üzemeltető szemszögéből. - Sínek Világa 59(3): 31-35.

HájEK M., HÁKJovÁ P. \& Apostolova I. (2005): Notes on the Bulgarian wetland flora, including new national and regional records. - Phytologia Balcanica 11: 173-184.

HAszonits G. \& SchmidT D. (2018): A potenciálisan inváziós vesszős aggófú (Senecio inaequidens DC.) aktuális elterjedése. - Kitaibelia 23(2): 179-187.

Hughes K. A., Convey P., Maslen N. R., \& Smith R. L. (2010): Accidental transfer of non-native soil organisms into Antarctica on construction vehicles. - Biological Invasions 12(4): 875-891.

HusBy C. (2013): Biology and functional ecology of Equisetum with emphasis on the giant horsetails. The Botanical Review 79(2): 147-177.

JÁVoRKA S. (1924): Magyar Flóra (Flora Hungarica). Magyarország virágos és edényes virágtalan növényeinek meghatározó kézikönyve. - Studium (Királyi Magyar Egyetemi Nyomda), Budapest.

KALINOWSKI P., SLIWINSKA E. \& KRUK J. (2016): Equisetum × moorei Newman (Equisetaceae) - a 'new' nothotaxon in the Polish flora. - Biodiversity Research and Conservation 41(1): 11-18.

KiRÁlY G. (szerk.) (2009): Új Magyar Füvészkönyv. Magyarország hajtásos növényei. Határozókulcsok. Aggteleki Nemzeti Park Igazgatóság, Jósvafő.

KiRÁlY G. \& KirÁLY A. (2018): Adatok és kiegészítések a magyar flóra ismeretéhez III. - Botanikai Közlemények 105(1): 27-96.

Krahulec F., Hrouda L. \& KovÁŘová M. (1995): Production of gametophytes by Hippochaete (Equisetaceae) hybrids. - Preslia 67: 213-218.

LUBIENSKI M. (2010): Die Schachtelhalme (Equisetaceae, Pteridophyta) der Flora Deutschlands - ein aktualisierter Bestimmungsschlüssel. - Online-Veröffentlichungen des Bochumer Botanischen Vereins 2(6): 82-100.

LUBIENSKI M, JÄGER W. \& BENNERT H. W. (2011): Equisetum xascendens Lubienski \& Bennert (Subg. Hippochaete, Equisetaceae), eine neue Schachtelhalm-Sippe für die Flora Nordrhein-Westfalens. Online-Veröffentlichungen des Bochumer Botanischen Vereins 3(1): 1-14.

lukács B. A., Gulyás G., Horváth D., Hôdör I., Schmotzer A., Sramkó G., TaKÁcs A. \& Molnár A. (2017): Florisztikai adatok a Tiszántúl középső részéről. - Kitaibelia 22(2): 317-357.

MALATINSZKY Á. (2002): Lycopsis arvensis L. az Upponyi-hegységben. - Kitaibelia 7(2): 281.

MALATINSZKY Á., MravcsiK Z. \& DedÁK D. (2014): Florisztikai adatok a Cserhát felhagyott szőlőiből. Kitaibelia 19(2): 260-266.

Maruşca T., Memedemin D., Groza A., Pop O. G., Simion I., Tîbîrnac M. N., Maftei D. I., Mărunțiu M., Taulescu E. \& MARIN N. (2020): Indicator species for soil ecological factors found in the natural habitat 62C0* Ponto-Sarmatic steppes from Rosci 0201, North Dobrogean Plateau. - Romanian Journal of Grassland and Forage Crops 21: 7-17.

Matus G., Aszalós R., Dorotovič Cs., Hanyicska M., Hűvös-Récsi A., Musicz L., MiglÉcz T., PAPp M., Schmotzer A., TöröK P., VAlKó O., VojtKó A., HARTMAnN J., TAKÁcs A. \& BALOGH R. (2019): Kiegészítések a magyar flóra ismeretéhez. - Botanikai Közlemények 106(1): 71-112.

MElzER H. \& BARTA TH. (2001): Cotula coronopifolia, die Laugenblume, neu für Österreich und anderes Neue zur Flora von Wien, Niederösterreich und dem Burgenland. - Linzer biologische Beiträge 33(2): 877-903.

MoLnÁR Cs. (2001): A Cenchrus incertus M.A. Curtis és a Tragus racemosus (L.) All. vasúti sínek mentén. - Kitaibelia 6(2): 407.

Molnár Cs., Haszonits Gy., Malatinszky Á., Kovács G. K., Kovács G., Nagy T., Molnár V. A. \& TaKács A. (2017): Pótlások Magyarország edényes növényfajainak elterjedési atlaszához III. - Kitaibelia 22(1): 122-146.

Molnár Cs., Haszonits Gy., Malatinszky Á., Süveges K., BAlogh L., NAGY T., Horváth S. \& HudÁK K. (2018): Pótlások Magyarország edényes növényfajainak elterjedési atlaszához VI. - Kitaibelia 23(1): 87-102.

Molnár Cs., Haszonits Gy., Pintér B., Korda M., Peregrym M., NótÁri K., Malatinszky Á., Toldi M. \& Beránek Á. (2019): Pótlások Magyarország edényes növényfajainak elterjedési atlaszához IX. - Kitaibelia 24(2): 253-256.

MolnÁR Cs. \& JUHÁSz M. (2016): Az alacsony libatop (Chenopodium pumilio R.Br.) Zuglóban és új adatok Északkelet-Magyarország idegenhonos fajainak elterjedéséhez. - Kitaibelia 21(2): 221-226. 
Molnár Cs., Lengyel A., Molnár V. A., NAgy T., CsÁBi M., Süveges K., LengYel-VASKor D., Tóth Gy. \& TaKÁcs A. (2016): Pótlások Magyarország edényes növényfajainak elterjedési atlaszához II. - Kitaibelia 21(2): 227-252.

MolnÁR V. A., MolnáR A., VidéKI R., PfEIFFER N. \& GulYÁs G. (2000): Néhány adat Magyarország flórájának ismeretéhez. - Kitaibelia 5(2): 297-303.

PinKE Gy. \& PÁL R. (2001): Adatok a Kisalföld flórájának ismeretéhez I. - Kitaibelia 6(2): 381-400.

Pinke Gy., PÁl R., Mesterházy A., KirÁly G., Szendrődi V., Schmidt D. \& UGHY P. (2006): Adatok a Dunántúliközéphegység és a Nyugat-Magyarországi peremvidék gyomflórájának ismeretéhez II. - Kitaibelia 10(1): 154-185.

Pinke Gy., Schmidt D., Schmidmajer Á., KirÁLy G. \& UGHY P. (2003): Adatok a Dunántúli-középhegység és a Nyugat-Magyarországi peremvidék gyomflórájának ismeretéhez I. - Kitaibelia 8(1): 161-184.

ScнмiDT D. (2015): Adatok a Kisalföld flórájának ismeretéhez III. - Botanikai Közlemények 102(1-2): 61-84.

Soó R. \& MÁTHÉ I. (1938): A Tiszántúl flórája. Flora Planitiei Hungariae Transtibiscensis. - Editio Instituci Botanici Universitatis Debreceniensis, Debrecen.

Sutyinszki Zs., Szentes Sz., Katona Z., Puszta E., Marinkás Á. \& Penszka K. (2013): Kondorosi mezsgyék növényzete és tájtörténete közötti összefüggések vizsgálata. - Tájökológiai Lapok 11: 379-388.

Süveges K., TAKÁCs A., NAGY T., Schmotzer A. \& Koscsó J. (2020): Florisztikai adatok a Tiszántúl északi pereméről II.: Borsodi-ártér és Sajó-Hernád-sík. - Kitaibelia 25(2): 169-186.

Szollát Gy., Seregélyes T., CSOMós Á. \& STANDOvÁr T. (2007): The flora and vegetation of Gödi Láprét near Göd, Pest county, Hungary. - Studia Botanica Hungarica 38: 155-178.

SzUjKó-LACZA J. (szerk.) (1982): The flora of the Hortobágy National Park. - Akadémiai Kiadó, Budapest.

TAKÁCS A. \& LÖKI V. (2015): Néhány adat Debrecen urbán-flórájához. - Kitaibelia 20(1): 168-170.

TAKÁCs A., NAGY T., FeKETE R., LovAs-Kiss Á., LJUBKA T., LÖKI V., LisZTES-SzABó Zs. \& MolNÁR V. A. (2014a): A Debreceni Egyetem Herbáriuma (DE) I.: A „Soó Rezső Herbárium”. - Kitaibelia 19(1): 142-155.

TakÁcs A., Nagy T., SRamkó G., Lovas-Kiss Á., Süveges K., LukÁcs B. A., Fekete R., LöKi V., Malatinszky Á., E. Vojtkó A., Koscsó J., Pfliegler W. P., NótÁri K. \& Molnár V. A. (2015b): Pótlások a Magyarország edényes növényfajainak elterjedési atlaszához I. - Kitaibelia 21(1): 101-115.

TAKÁcs A., SÜveges K., LjuBkA T., LöKI V., LisZTes-Szabó Zs. \& MolnáR V. A. (2015a): A Debreceni Egyetem Herbáriuma (DE) II.: A „Siroki Zoltán Herbárium”. - Kitaibelia 20(1): 15-22.

TAKÁCS A., ZÁKÁNY A., GulYÁs G., Koscsó J. \& SRAmKó G. (2014b): Florisztikai adatok a Tiszántúl északi pereméről. - Kitaibelia 19(2): 275-294.

TAKÁCS A. \& ZsólYomi T. (2011): Adatok a Taktaköz flórájának ismeretéhez. - Kitaibelia 15(1-2): 25-34.

Tóтн T. (2003): Újabb adatok a Dél-Tiszántúl flórájának ismeretéhez. - Puszta 20(1): 135-170.

TóTH I. Zs. (2018): Botanikai adatok Tolnából és Baranyából III. - Kitaibelia 23(1): 39-50.

VIDÉKI R. (2009): III. Galium L. - Galaj. - In KIRÁLY G. (szerk.), Új Magyar Füvészkönyv. Magyarország hajtásos növényei. Határozókulcsok. - Aggteleki Nemzeti Park Igazgatóság, Jósvafó, pp. 388-393.

VynoKURov D. (2021): New and validated names of some syntaxa of the Festuco-Brometea class vegetation from Eastern Europe. - Chornomorski Botanical Journal 17(1): 76-80.

Willard T. R., Hall D. W., Shilling D. G., Lewis J. A. \& CurRey W. L. (1990): Cogongrass (Imperata cylindrica) distribution on Florida highway rights-of-way. - Weed Technology 4(3): 658-660.

WinTER W. P. \& LUBIENSKI M. (2012): Equisetum ×ascendens Lubienski \& Bennert: de eerste triploïde paardenstaartbastaard in Nederland. - Gorteria 36(1): 1-17.

WoŁKOWICKI D. \& BANASZUK P. (2016): Railway routes as corridors for invasive plant species. The case of NE Poland. The International Academic Conference: On the New Silk Road Connectivity Symposium, 5-6 November 2016, Chongqing, China, Conference Proceedings, Chongqing Jiaotong University, pp. 162-169.

ZLINSKÁ J. (1995): Dauco-Equisetetum $\times$ moorei - a new synanthropic community in Slovakia. - Biologia 50: 33-36.

Beérkezett / received: 2021. 03. 08. • Elfogadva / accepted: 2022. 01.17.

Elektronikus melléklet / Electronic appendix

e1. ábra Zsurlótelepek a vasúti töltések mentén Karcag határában

Fig. e1 Colonies of horsetails along the railways on the confines of Karcag

e2. ábra Zsurlótelepek a vasúti töltések mentén Püspökladányban

Fig. e2 Colonies of horsetails along the railways in Püspökladány railway station

e3. ábra A Galium humifusum élőhelye Törökszentmiklón

Fig. e3 Habitat of Galium humifusum at Törökszentmiklós 
KIS Szabolcs (2022):

Adatok a vasútmenti pionír élőhelyek flórájához a Tiszántúlon

Contributions to the flora of railway-side pioneer habitats on Tiszántúl region

Kitaibelia 27(1): 86-101.

DOI: $10.17542 /$ kit.27.001

Elektronikus melléklet / Electronic appendix

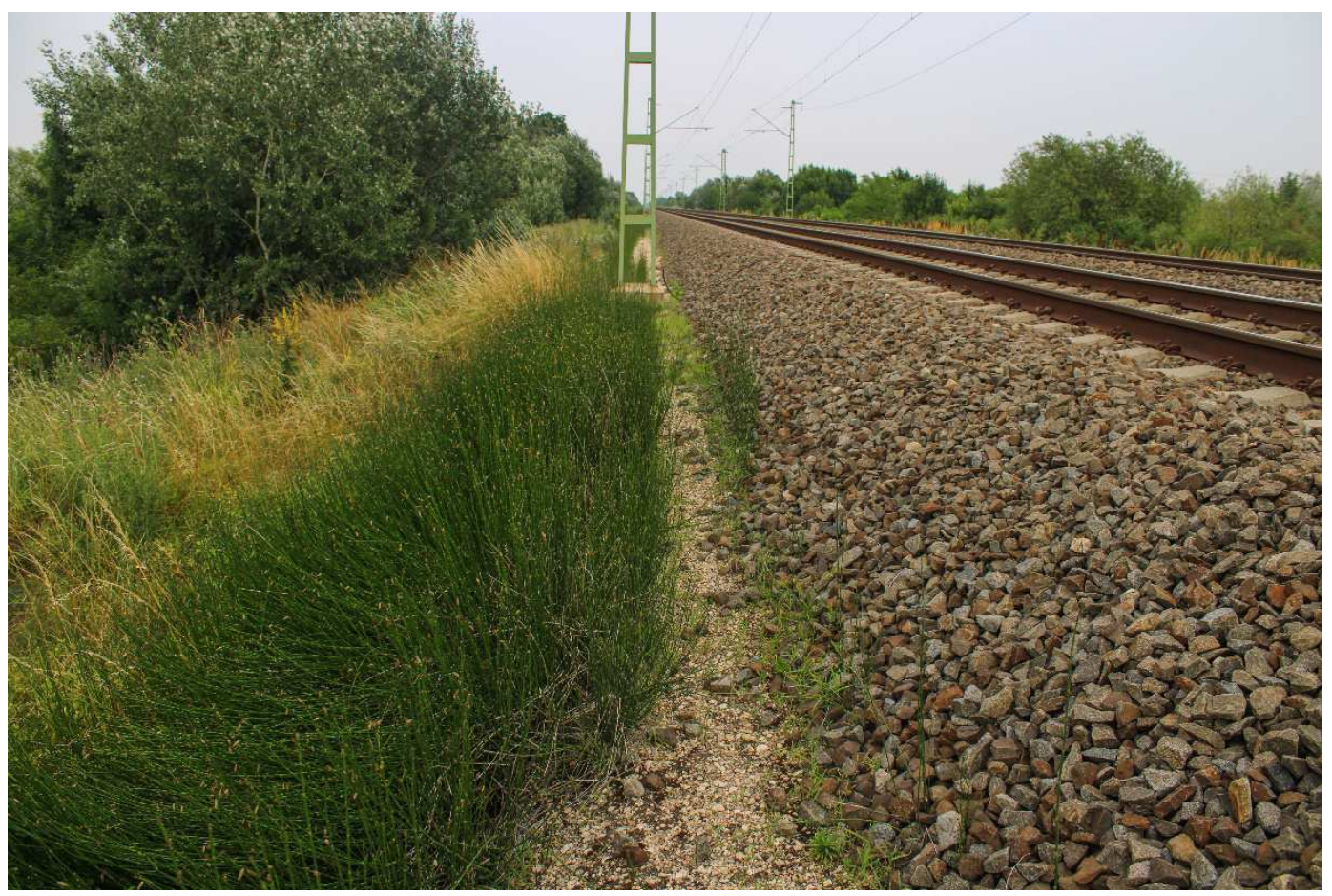

e1. ábra Zsurlótelepek a vasúti töltések mentén Karcag határában

Fig. e1 Colonies of horsetails along the railways in the edge of Karcag 
KIS (2022): Adatok a vasútmenti pionír élőhelyek flórájához a Tiszántúlon

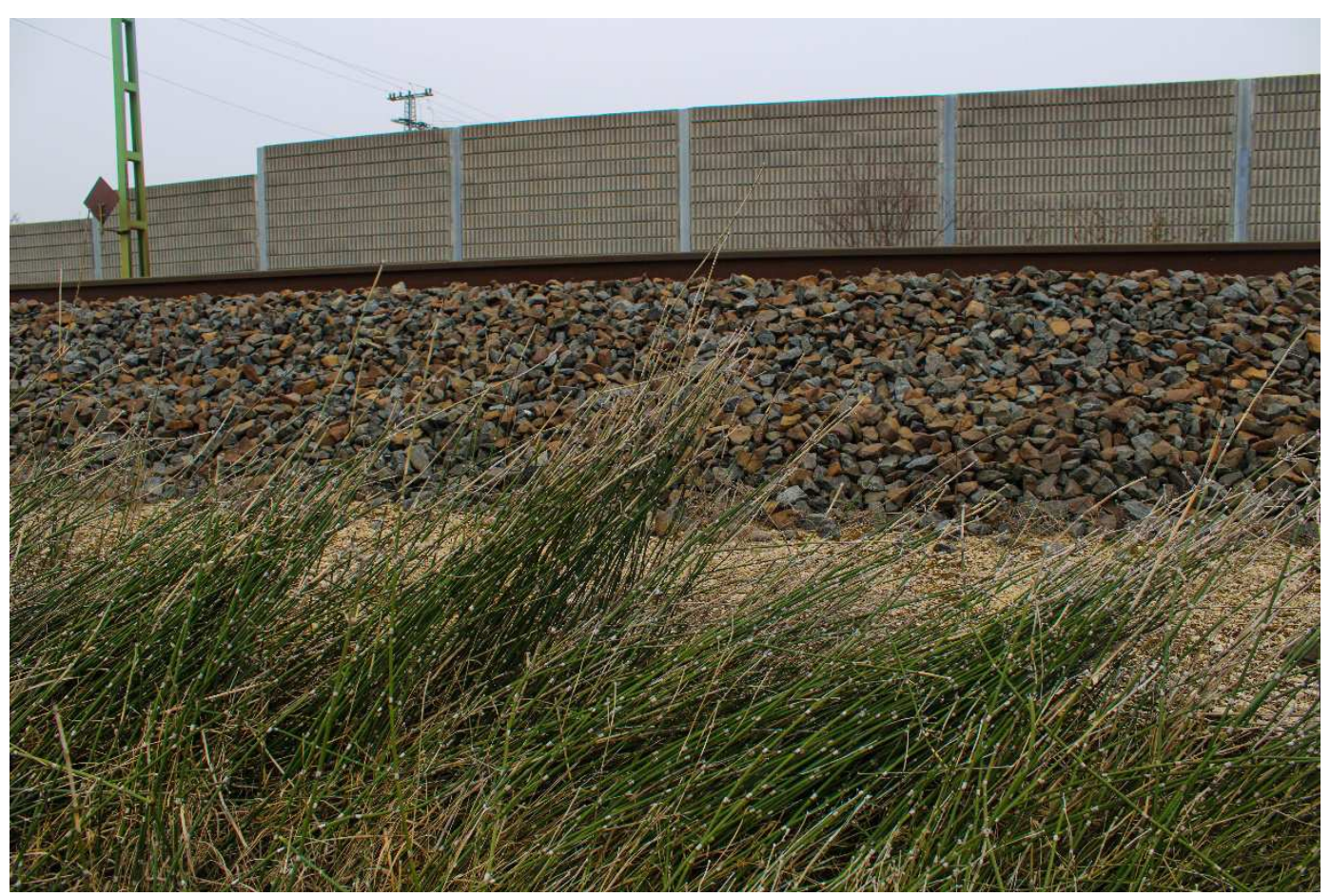

e2. ábra Zsurlótelepek a vasúti töltések mentén Püspökladányban

Fig. e2 Colonies of horsetails along the railways in Püspökladány railway station

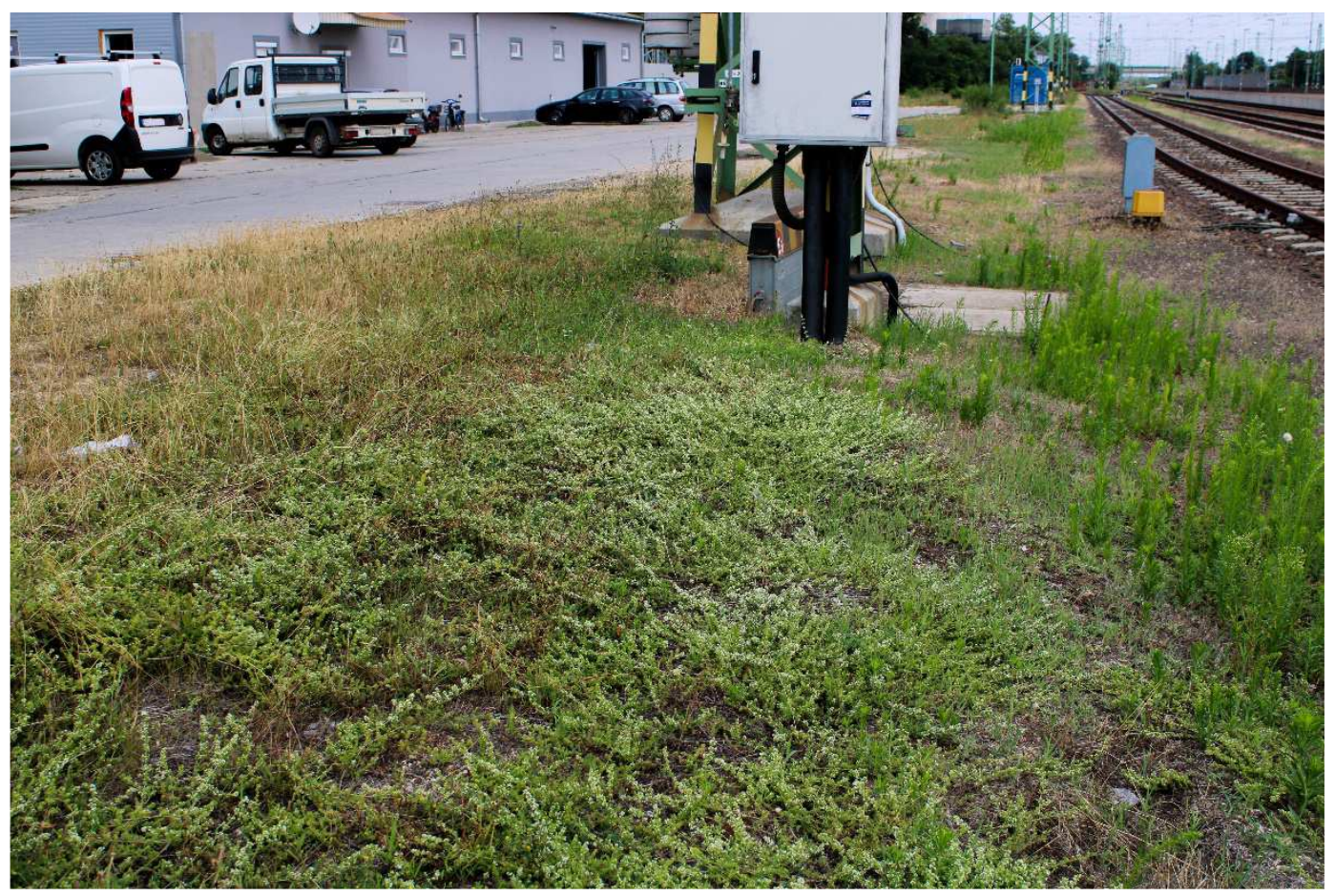

e3. ábra A Galium humifusum élőhelye Törökszentmiklón

Fig. e3 Habitat of Galium humifusum at Törökszentmiklós 